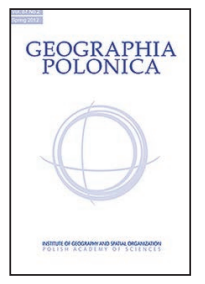

\title{
SELECTED PROBLEMS OF CONTEMPORARY SOCIO- -SPATIAL CHANGES IN PERI-URBAN AREAS OF THE CITY OF ŁÓDŹ (POLAND)
}

\author{
Marcin Wójcik \\ Department of Regional and Social Geography \\ University of Łódź \\ Narutowicza 88, 90-139 Łódź: Poland \\ e-mail: marcin.wojcik@geo.uni.lodz.pl
}

\begin{abstract}
The main aim of this paper is attempt to identify the effects of social and spatial transition in a specific area of peri-urban rural municipalities associated with large Polish cities (in this case: Łódź). The issues of social, economic, as well as landscape transformations of peri-urban areas are discussed very frequently in geographic, sociological and architectural studies. Unlike macro-scale studies, both Polish and foreign, micro-scale studies have shown that differences are even greater and concern neighbouring areas. As a result of the influx of new residents to suburbanising villages, long-time communities of agrarian origin evolve towards social and spatial disintegration. The different ways of life are manifested in different behaviour patterns and levels of territorial identity. Examples of studies on the evaluation of the local living environment show that the social coherence of the countryside is gradually weakening, resulting mostly from more and more varied lifestyles, social needs, and expectations towards their place of residence.
\end{abstract}

\section{Key words}

peri-urban area $•$ rural settlements $\cdot$ socio-spatial processes $•$ Łódź Metropolitan Area

\section{Introduction}

The issues of social, economic, as well as landscape transformations of peri-urban areas are very frequently discussed in geographic, sociological and architectural studies (Tammaru 1999; Phillips 2005; Bański 2008; Bański \& Wesołowska 2012). The reason for this interest is the relatively active dynamics of the phenomena, as well as the tensions and conflicts that form when the different economic and social functions for which the peri-urban setting is now very attractive develop. The spatial transformations (forms of land use and architecture) arising as a consequence of the social and economic changes in urban regions in post-socialist countries are already fairly well documented. In Poland, 
a great deal of attention is paid to the issue of chaotic urbanisation as an effect of careless and short-sighted policies, and to its environmental, financial and social consequences (Śleszyński 2014).

The question of shaping the housing environment in the suburbanisation process is also an interesting problem. Typically, most attention is paid to the spread of housing (location) and related functions, as well as to the transport accessibility of residential areas to the centres of urban areas (Komornicki 2013; Śleszyński 2014). Areas that could benefit from more attention are the social conditions of suburban transformations as far as human behaviour (motivations, perceptions) is concerned, the activity of local communities, the relationships between newly arrived and older residents, and the occurrence of various social conflicts.

The paper discusses the problem of the formation of local housing environments in rural areas in which individual housing construction has been developing over the last 10-15 years. The list of topics and research methods that can be used is very long. For this research project, we decided to present the social and spatial transformation on a micro scale, i.e. within chosen rural settlements that have undergone spatial and architectural changes. The study has focussed on the causes for settlement in villages of the metropolitan fringe villages, as well as on the location principles for new housing developments. Furthermore, attention was paid to the symbolic plane, i.e. an attempt was made at determining identification with the rural environment and chosen aspects of perception of the social and spatial transformations.

\section{Rural human ecology and the concept of the metropolitan village}

A post-socialist city in a broad sense (including other functional areas of urban regions) is very interesting for researchers from the countries that went through a social and economic transformation, including from other parts of Europe and the world (Sýkora 1999; Blacksell \& Born 2002; Węcławowicz 2002 Kovács 2009). The main reason is the reconstruction of spatial structures, especially of large cities, under the influence of various factors of economic transformation, globalisation or the impact of European funds.

In Polish scientific works, the problem of suburban transformation was widely discussed in the previous political and economic systems, i.e. the centrally-planned economy, in the transitional period, and after Poland joined the European Union. Attention was primarily paid to functional changes, planning issues and the transformations of the spatial structure (Straszewicz 1985; Jakóbczyk-Gryszkiewicz 1998; Gierańczyk \& Kluba 2008; Świq̨tek 2010; Biczkowski \& Kozłowski 2015).

In recent years, the studies of transformations in peri-urban rural areas involved analyses of the phases of urbanisation within the discussion of the life cycle of urban regions (Champion 2001; Geyer 2002). In the case of post-socialist countries, the researchers also pointed out the dynamic character of suburbanisation (the return to free land sale) and the need for some inhabitants to move to more elite estates in the suburbs. Studies also stressed the complex social nature of the process of urbanisation, resulting from different motivations of migration (Tammaru 1999; Ouředníček 2007; Boren \& Gentile 2007). The social and cultural aspects of suburban transformations have sparked considerable attention from researchers (Wójcik 2010; Kajdanek 2011, 2012; Mantey 2011). The authors point out that the spontaneity of the transformation process creates a series of tensions in local communities, which often contradict the image of the rural area as a harmonious environment (the rural idyll myth).

Given that these proposals were primarily formulated by specialists in urban processes, little attention was paid to the transformations of post-agrarian structures in periurban villages. This was discussed, among others, by Phillips (2002, 2005), who used the 
example of English countryside to interpret the transformations of local communities under the impact of an invasion of new inhabitants (gentrification of the countryside). In the case of the peri-urban areas of large post-socialist cities, the concept of human ecology in the context of metropolitan processes assumes a new meaning. The main aim of research within this concept is to define the relations between the society and the territory (social space). Territorial identity (placeness) is an important component of local identity (Sibley 1999), as well as an important condition for the emergence of local social and territorial cohesion.

The concept of human ecology is of great utility in the study of urban fringe, especially around cities with well-developed metropolitan functions. New residential areas, which are typically emerging in the vicinity of existing settlements, differ not only in architecture and land development. They are inhabited by people with different material status and lifestyle. Research conducted in the 1960s in many developed countries (including the United Kingdom and the United States) undergoing suburban sprawl have proven that one of the most important effects of migration to rural areas around around urban metropolises was the emergence of vast social inequalities (Pahl 1965; Connell 1974).

The study of the spatial effects of social change in peri-urban areas has led to the formulation of the concept of a metropolitan village included in the geographic reviews of the research problems of urban areas (Clark, 1982), as well as rural areas (Pacione 1984). The issue of the pervasive spread of urban and rural influences in the vicinity of big cities sparks considerable interest in the social sciences, including human geography. Areas with the most advanced social change in urban environments are variously described in the literature as the edge, fringe, suburbs. Theoretical foundations for the studies of the metropolitan countryside have been outlined by such researchers as Pahl (1965) and Connell (1974). Studies utilising this research context mainly relate to the social and spatial transformations in the countryside surrounding big cities (usually some distance from the city, but still in the zone of everyday contact with the city, i.e. in the commuter zone). The planning concept of the metropolitan countryside was a form of defence against uncontrolled urban sprawl. Metropolitan villages have been created on the outskirts of large metropolitan areas (such as London) in order to concentrate the suburbanisation processes while protecting the values of rural landscape (process control). The concept of the metropolitan village was most widely disseminated by the British researcher R. Pahl (1965). Studies stressed that, in qualitative terms, metropolitan villages are a new spatial and social form (Pahl 1965: 72). Although the settlement resembles an urban district or a small wellorganised town, formally it is located in the rural area. In social terms, such settlements are a selected group of people with a similar status (middle class). One common feature of people living in such settlements is their high daily mobility realised using private transport. It was noticed that a concentration of people with a similar, relatively high social status and specialised function leads to the distortion of the geographical (spatial) and social hierarchy. The concept of the metropolitan village was one of the elements in a wider discussion concerning the 'dispersed city' and the relocation of urban functions within urban (metropolitan) regions.

Poland is experiencing a problem resulting from the dynamic, uncontrolled spread of development in peri-urban areas. The trade in land and the direction of construction are products of the interests of the actors participating in this process - local communities, developers, local authorities and private investors. There have been no universal standards so far adopted that would foster spatial order in peri-urban villages (Gutry-Korycka 2005; Wójcik 2013a). In Poland, after 25 years of the free market in land and in view of the growing pressure on rural areas around big cities, spatial forms categorised as metropolitan villages according to R. Pahl or J. Connell are hard to find. 
Observations on the advance of post-socialist suburbanisation after 1990 allow us to identify the beginnings of settlement forms that can be cautiously interpreted as metropolitan villages, though the term rural metropolitan settlements would be more appropriate.

The theme of socio-spatial diversification has never been seriously tackled in studies in rural geography. Similarly to their Englishspeaking counterparts, Polish geographers mostly concentrated on the socio-spatial diversification of cities, e.g. on spatial segregation (Węcławowicz 1979; Smith 1989; Wessel 2000). The decreased interest in rural human ecology in Poland stemmed mostly from the socio-spatial homogeneity of rural communities and the small number of rural settlements (Pióro 1982: 42). Polish economic geography focused on the factors and effects of rural production (socialist period).

People in the countryside meet not only social, but also natural structures. Therein lies the fundamental difference in the formation and interpretation of the specific characteristics of rural life in the conditions of the ever decreasing importance of production functions (mainly agriculture). A significant difference between the city and the countryside lies in the role of nature in creating social and territorial individuality (Macnaghten \& Urry 1998), since nature not only creates the foundations for productive but, more and more often, also consumption behaviour in the countryside (Woods 2011). In rural space, the concept of human ecology has a real sense arising from the relationship between the natural, social, and material structures. Due to a different scale of settlement (micro) studies, the term ecological niche seems more appropriate than ecological area (Pióro 1982: 49). Ecological niches are historically-shaped spatial complexes with different material (physiognomic, residential standard) and social characteristics. An ecological niche is characterised by the cohesion of spatial (landscape) features of settlements with the social features of its inhabitants. In contrast to the 'urban' tradition of studying social areas, the term 'niche' is more appropriate in relation to the scale of research (micro-scale).

In the past, especially in feudal times, most villages in Poland were homogeneous cultural and economic systems (rural culture). Traditional (agricultural) villages were uniform in both the social and architectural sense (Starosta 1995; Gorlach 2004). Today's rural settlements, especially in metropolitan areas, are becoming complexes of ecological niches, and the question whether there is anything more connecting "the 'new' and the 'old" than physical proximity becomes an important research problem (Wójcik 2013a).

\section{Methodological issues and the case study}

The study was conducted in rural areas in the Łódź Metropolitan Area. The City of Łódź is currently the third Polish city in terms of population, and its origin is associated with a rapidly growing textile industry in the late nineteenth and early twentieth centuries hence the city is often compared to Manchester in the UK (see Liszewski 1997). Until the end of the 1980s, Łódź Metropolitan Area was plagued by vast contrasts between the highly developed urban area of Łódź and other towns in the conurbation (Suliborski et al. 2009) and the extensive rural development of their immediate surroundings. Researchers pointed out that the textile industry in Łódź failed to activate suburbanisation processes, identifying one of the main reasons for this situation as the large number of people of low social status in the social structure.

Compared to other large Polish cities, the peri-urban area of Łódź is much less developed. In the early 1980s, regional statistics called areas with dominant agricultural functions 'open areas'. In the case of the Łódź Metropolitan Area, open areas included most rural communities bordering the city of Łódź (GUS 1984). Most villages located in the vicinity of Łódź started undergoing vast changes during the social and economic transformation (1990s), especially under the influence of the residential function in the circumstances 
of suburbanisation and the development of personal car transport (Wójcik 2008; Jakóbczyk-Gryszkiewicz et al. 2010).

The rural areas of Łódź Metropolitan Area are thus an interesting case study of rural transformations that significantly changed the social and economic structure over a relatively short period of time (10-15 years). It can be said, that the choice of such a case study allowed us to observe the processes in statu nascendi ('under development'). It is important in the case of social studies, as the information gathered from the participants (creators) has not yet been erased from their memory. On the other hand, learning about local social communities was also vital as their inhabitants are both new and long-term residents of the countryside who observe one another, thus fostering the formation and retention of opinions about the neighbourhood environment.

Seventeen villages were selected for field studies (Fig. 1). This selection was preceded by local inspection of rural settlements in the
Łódź Metropolitan Area, i.e. in Zgierz poviat (district) - the municipality of Zgierz, Stryków Aleksandrów Łódzki; in East Łódź poviat (district) - the municipality of Nowosolna, Andrespol, Brójce, Rzgów; and in Pabianice poviat (district) - the municipality of Ksawerów, Pabianice, Lutomiersk. The selection of villages was dictated by the specificity of their functional and spatial structure, i.e. the settlements whose intense transformations started in the 1990s (usually late 1990s), and whose proportion of developed (built-up) plots formed from $20 \%$ to $50 \%$ of the total area of the settlement.

The primary aim of the empirical research was the identification of the basic rules concerning the transformations occurring in the spatial structure of the settlements and the ways in which new residential developments are incorporated into existing rural settlements. As a result of a detailed inventory of 17 villages, 1293 plot cards were created. The data collected included information which mainly concerned the character of development,

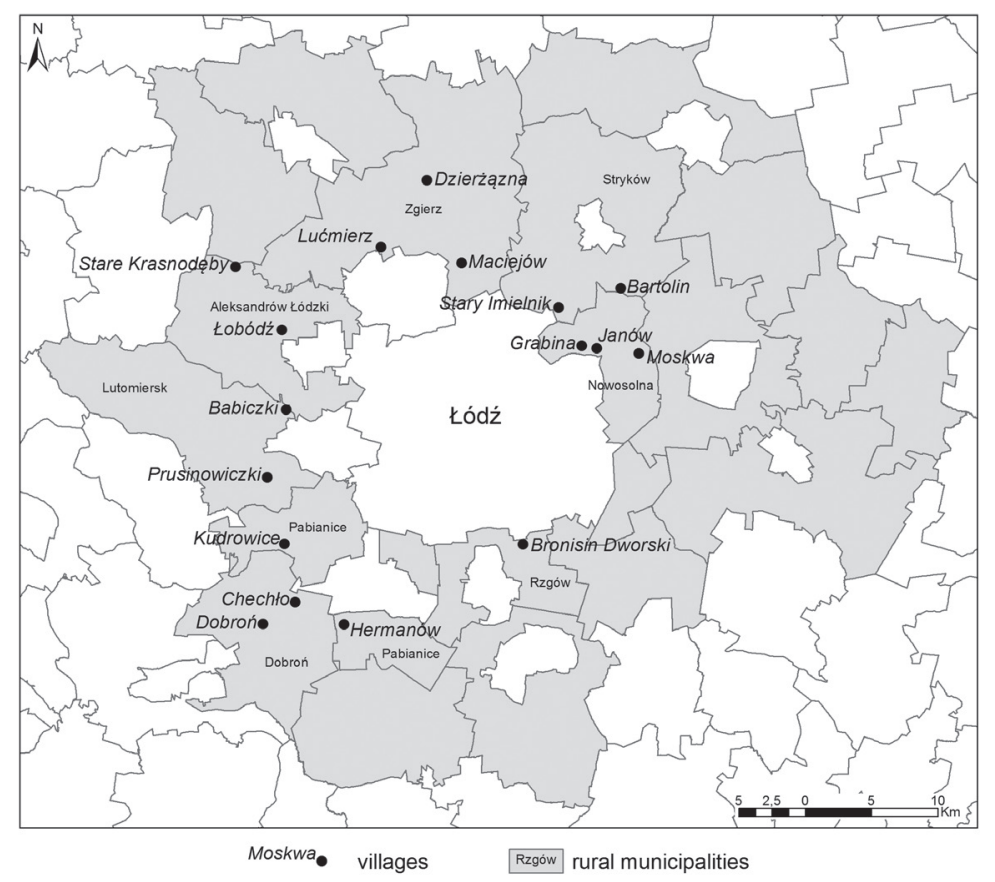

Figure 1. Villages selected for field studies 
i.e. the date of its construction, number of facilities, their layout and utilisation (function). This group included 685 cards concerning new residential buildings created in the period 1995-2012 (new buildings). This helped in the identification of new buildings which could be compared to the development at the beginning of the 1990s. The result is a classification of the ways of combining new residential areas with the structure of rural settlements (spatial cohesion).

The second aim of the empirical research was to determine the degree of social cohesion on the basis of the perception of the specific features of the modern countryside (which is undergoing deagrarianisation) and the values of rural environment, as well as the level of territorial identification. Were also trying to determine the motives for new residents' choice of a village as a place of residence. In total 301 interviews were conducted in the villages, 114 (38\%) with new residents and 187 (64\%) with long-term residents. A total of 15 to 25 interviews, including members of both groups, were conducted with residents in each village.

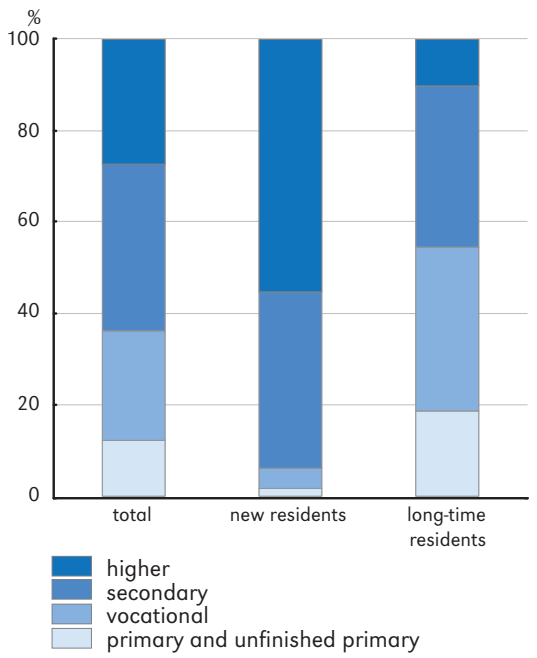

Figure 2. Respondents by level of education (\%)

New rural residents mainly come from the core of the metropolitan area, i.e. from the city of Łódź (Urzad Statystyczny w Łodzi
2008; Wójcik 2008; Jakóbczyk-Gryszkiewicz et al. 2010). They are mostly university or high school graduates, while many (approx. 50\%) of the long-term residents declared only primary or vocational education (Fig. 2).

The situation with professions seems similar. Over $75 \%$ of newly settled respondents declared that they were entrepreneurs or hired employees of private or public sector organisations (Fig. 3), so their workplaces were located outside the countryside (92\%). In the case of the long-term population, categories such as farmer, hired employee in the private sector, pensioner and unemployed were quite popular.

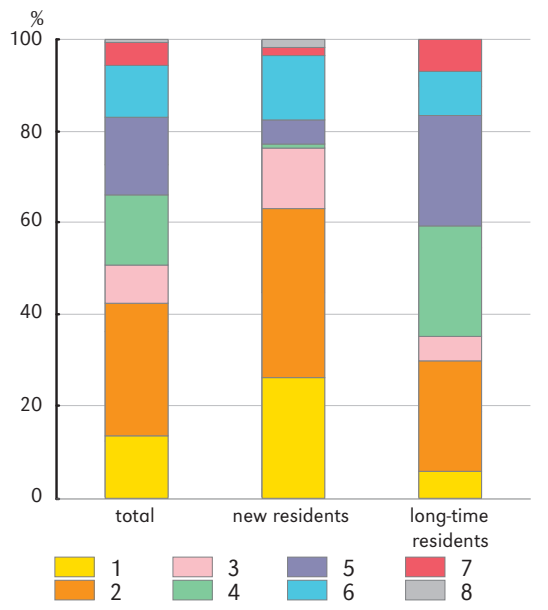

Figure 3. Respondents by occupation (type of economic activity) (\%)

Professional activity: 1 . hired employee in the public sector, 2. hired employee in the private sector, 3. entrepreneur, 4. farmer, 5. retiree, pensioner, 6. student, 7. unemployed, 8. undetermined

\section{Why do I want to live in the countryside?}

The reasons given for seeking a place to build a house tell us a lot about societal needs, as well as indirectly showing us the directions of functional transformations in peri-urban villages. New residents of the countryside were asked to justify their choice of the village where they decided to build a house and live (Fig. 4). In this case, the respondents were asked 
to point to the most important factor (motive) for making a decision and which persuaded them to choose their place of residence.

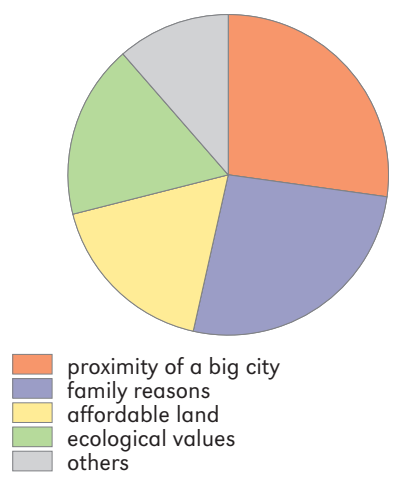

Figure 4. The structure of responses to the question on the main motivation for the choice of a particular village as a new place of residence (\%)

The responses of the new inhabitants in the countryside were varied and none of the motives identified during the categorisation process were dominant. Most respondents referred to the proximity of the villages in relation to the centre of the metropolitan area (approx. 27\%). This motivation was equally valid for distance and good accessibility, thus ensuring comfortably short rides to (and from) workplaces and schools, and the fulfilment of various daily needs. Comfortable communication between the place of residence (countryside) and the workplace (city) is one of the key factors in deciding to move. It is important because new residents often have families with school-aged children. Moving out of the city is a decision which generally results in an increased burden in relation to commuting (bigger share of the time budget), especially when parents decide to improve their children's skills and have to drive them to educational institutions and other services (language classes, sports training) at a higher cost.

A high level of awareness when choosing a village is also proven by the responses relating to family. Their share was a little lower than the first motivation (proximity to the city). Interestingly, about $26 \%$ of the respondents quoted family reasons for building a house in a given village. This mostly consisted of seeking good locations in places the respondents had known a lot about. On the one hand, this is associated with a desire to bypass an intermediary (real estate agents). In Polish conditions, making such a profound decision as buying a plot and building a house, often taking a loan, is the effect of lengthy consultations with family, friends or acquaintances. The selection is made by relating it to existing social experience. Investors come back to the areas their families came from or choose an area where someone from their family already underwent the whole process of buying and developing land, or part of this process. Inheriting land (a settlement or part of a field), the struggle to transform its status in the land development plan (farmland conversion) or help from their family in buying their chosen plot are also large factors. Respondents often indicated that the proximity of their family, or good acquaintances, gives them support in hardship, especially in the case of families with children and in the initial stages of getting used to living in the countryside.

Land prices were also a significant factor in choosing a village. The economic factor was clearly visible in the villages further away from the centre of the conurbation or with less favourable communications. Respondents often said that a low land price was the only way to fulfil their dream of owning a house, noting that investing in a house means double costs, i.e. the cost of land purchase and the cost of construction. The increase in land prices, especially in 2007 and 2008 was an important factor inhibiting construction. Hence, investors began to look for smaller parcels, limiting the first major cost of investment. This factor is important, as the purchase of a plot also has a lot of hidden costs that cause an increase in the real price in the next stages of the project. The increase in costs is often associated with the construction of a private water supply, private road, snow removal in the winter, etc. 
Environmental and landscape considerations are of secondary importance (though they still play a significant role in the assessment and perception of the rural environment). Only about $17 \%$ of the respondents declared this was the deciding motivation in choosing their place of residence. The role of environmental factors (landscape) in the location of residential investments is usually large, though it is just an auxiliary factor for most respondents to the more functional factors (location, price, etc.).

The lack of care for social factors that stem from the character of local communities, such as the self-organisational ability of the community, building friendly relations, etc. is also interesting. The deficit of such factors may be explained mainly by the lack of opportunity to gain deeper knowledge about the complex system of relations within local communities that depend not only on the structure of this group, but also on historical circumstances. Social features become an important factor in the comfort of living in the countryside once a person moves to a given village, though, as we can see further below, not all new residents find this factor particularly important (individualism).

\section{How do I produce my living 'space'?}

One important factor shaping the landscape and physiognomic variety of commuter villages is the way in which new residential buildings are incorporated in the spatial structure (layout) of the settlement. The development of a complex spatial system of a settlement largely depends on the form that this settlement and the surrounding fields assumed during its historical development. Linear villages of various origins dominate in the peri-urban area of Łódź. Fields usually form long belts (Tkocz 1998). The internal structure of the settlement and fields is considered one of the genetic factors forming new spatial systems of rural settlement in Poland. The increased interest in the development of residential functions in areas outside of a big city resulted in the commencement of a process of conversion of farmland for other purposes. This resulted in a significant increase in construction land, especially in villages in the immediate vicinity of Łódź (Jakóbczyk-Gryszkiewicz 2009). The local authorities in the municipalities adopted their own spatial development policies, mostly under pressure from residents interested in selling their land, introducing documents favourable to farmland conversions and ad valorem divisions (Milewska-Osiecka 2010). This policy resulted in an uncoordinated process of transformation of traditional rural systems which lacks any basic logic that takes into account good spatial planning principles, i.e. striving to maintain spatial cohesion, agreement between forms and their surroundings, a sequential process of action and systemic thinking about the environment ('urban sprawl').

The impact of various circumstances stemming from the relationships between the actors participating in spatial transformations (local authorities, investors, sellers) results in a considerable diversity in the ways of incorporating new forms of rural development, especially residential areas, in the old spatial structures. The results of inventory and social research in peri-urban villages have led to some general conclusions concerning the character (method and directions) of the transformations over the last twenty years, as well as allowing a systematic classification of the types of development of spatial structure of the settlements. They concern building plots where new houses were constructed ${ }^{1}$.

Basic regularities concerning the transformation of the spatial structure relate to the following components of the process:

1. The structure of new residential spaces. The vast majority (92\%) of new homes were created on building plots formed from larger old structures, usually fields (belts of fields).

2. The nature of the trade in land. The majority $(84 \%)$ of building plots were purchased by private investors in direct transactions

1 These conclusions are based on 105 interviews with private investors. 
without any real estate agents. The purchase of a complete new house (from a developer) is a rarity in the urban-fringe around periurban areas of Łódź.

3. Investment location. The stabilisation of the original part of the settlement (the sellers offer plots formed from the fields, while they themselves rarely move), leads to the expansion of the settlement outwards. Decisions concerning location generally favour places (complexes of plots) where some construction has already been started. Attention is focused on functional and operational considerations, investment costs, accessibility, etc. In most cases (65\%) investors preferred their chosen locations to not be directly adjacent to the dwellings of long-term residents.

Another important aim of the study based on inventory information was an attempt to classify the methods of incorporating new residential areas into the existing structure of the settlement (Tab. 2).

The main two ways of including new buildings consist of marking out new settlement belts (Figs. 5, 6) and filling up empty space within the settlement (Figs. 7, 8). Private investors prefer plots with access to a public road. This is the result of their need for convenient access to their property and access to basic services, whose routing depends on the public road. Due to the limited amount of space available in such places, belts perpendicular to the main road are usually planned, with axes along private roads (coaxial), whose routing depends on the borders between field belts (former baulks). These plots also tend to be cheaper, due to the additional cost of supplying media to them. They also allow for more freedom in choosing the area of the

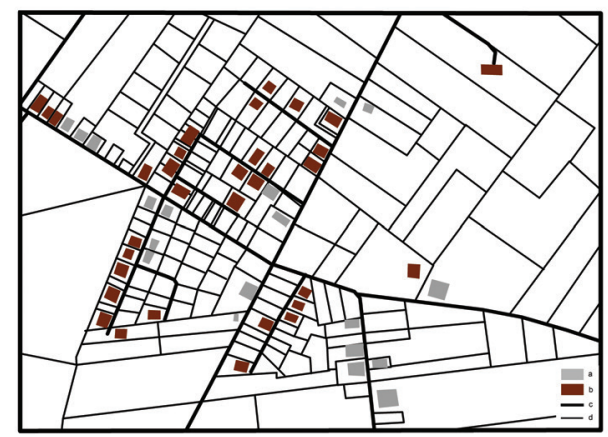

Figure 5. An example of the emergence of new settlement axes (perpendicular). Plichtów village; a. old housing, b. new housing, c. roads, d. boundaries of ownership plots

Source: Own compilation based on field work.

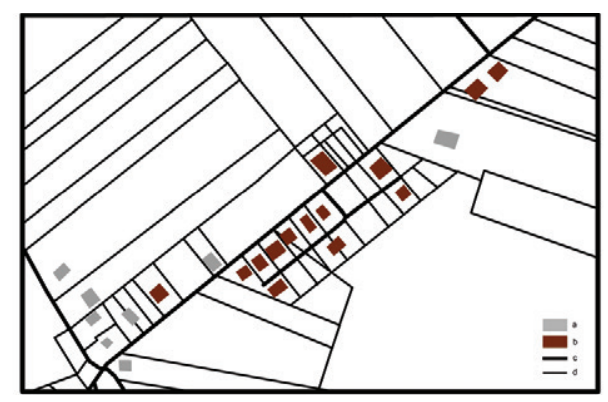

Figure 6. An example of the emergence of new settlement axes along a public road. Moskwa village; a. old housing, b. new housing, c. roads, d. boundaries of ownership plots

Source: Own compilation based on field work.

plot due to genetic reasons, i.e. the varied width of field belts left by the historical familial divisions.

The chaotic process of planning periurban villages, selective demand for land,

Table 2. Types of inclusion of new buildings into the structure of settlements

\begin{tabular}{|l|c|}
\hline \multicolumn{1}{|c|}{ Type of inclusion } & Percentage (\%) \\
\hline Filling the settlement by infill between developed plots & 20.6 \\
Filling the settlement on the opposite side of the axis & 10.5 \\
Extension of settlement along the developed axis (parallel) & 7.0 \\
The creation of new habitat axes (perpendicular to the existing axis) & 56.9 \\
Separation of new buildings from the settlement (a single building) & 2.9 \\
Separation of the new buildings (a complex of buildings) & 2.1 \\
\hline
\end{tabular}




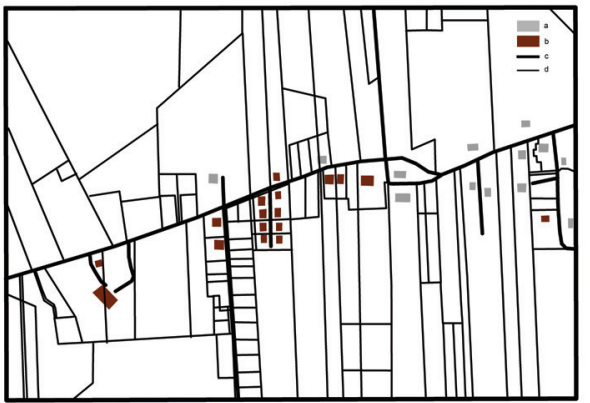

Figure 7. An example of the separation of new buildings (group of buildings). Grabina village; a. old housing, b. new housing, c. roads, d. boundaries of ownership plots

Source: Own compilation based on field work.

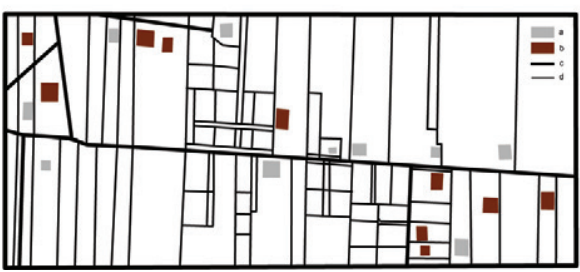

Figure 8. Example of infilling between developed parcels in a village. Bronisin Dworski village; a old housing, b. new housing, c. roads, d. boundaries of ownership plots

Source: Own compilation based on field work.

and the heritage of earlier development all lead to very variable patterns of emergence and inclusion of new buildings in the existing spatial systems of the countryside. This is an example of dynamic suburbanisation and chaotic development of rural space (urban sprawl). This process mainly results in the spatial separation of new and long-term residents, which weakens the spatial cohesion of rural settlements.

\section{The liquid countryside?}

Halfacree wrote that to identify rurality is to identify the various things that make somewhere, someone, or something rural (2009: 449). The definition of contemporary countryside by its residents is thus an important

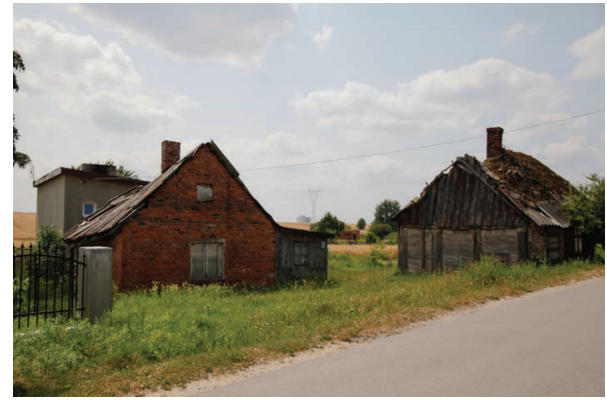

Figure 9. An example of the destruction of traditional buildings. Maciejów village (Zgierz municipality) Photo by M. Kossowski

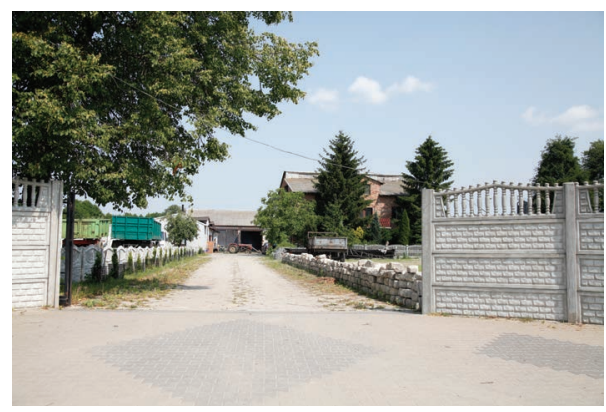

Figure 10. Example of traditional (agricultural) village planning. Dzierżąna village (Zgierz municipality) Photo by M. Kossowski

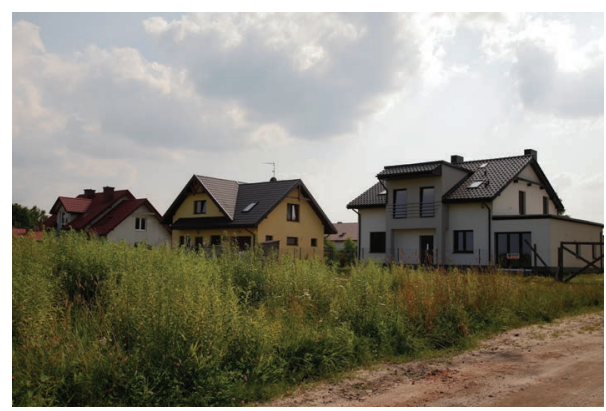

Figure 11. A complex of new residential buildings. Łobódź village (Aleksandrów Łódzki municipality) Photo by M. Kossowski

task. Referring to the images created by residents is one way to determine the nature of contemporary countryside (llbery 1998). This is largely due to our utter inability to define countryside based on traditional 


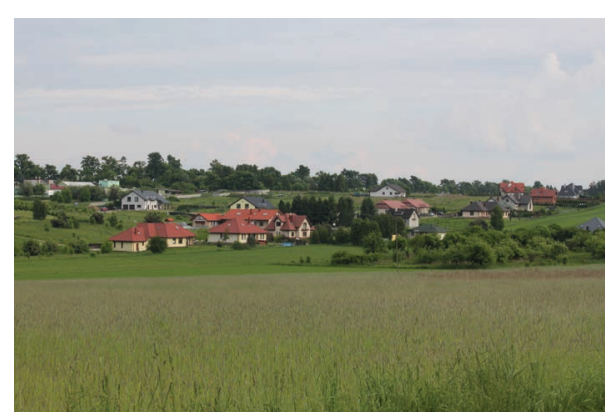

Figure 12. A group of new residential buildings. Plichtów village (Nowosolna municipality) Photo by M. Wójcik

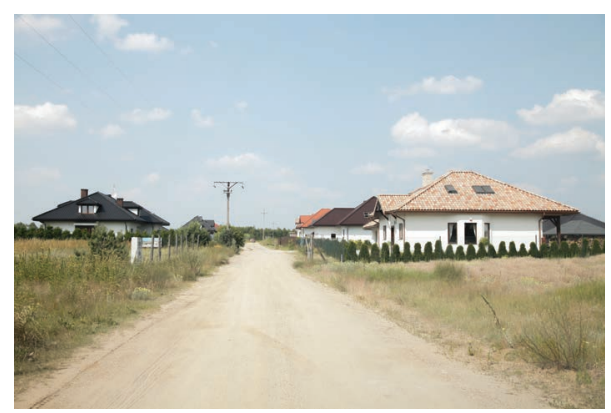

Figure 13. New settlement belt along a dirt road. Stare Krasnodęby village (Aleksandrów Łódzki municipality) Photo by M. Kossowski

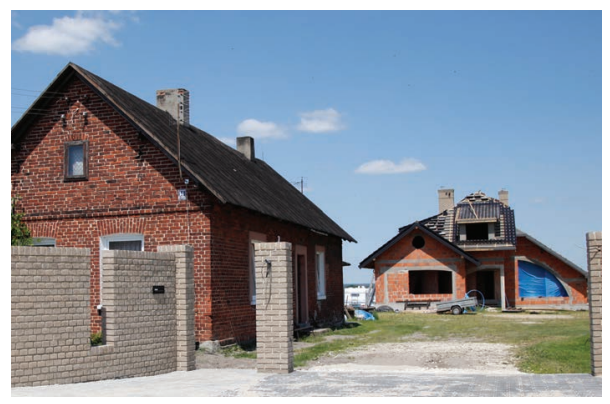

Figure 14. Infill within a settlement (former homesteads) with new buildings Kudrowice village (Pabianice municipality) Photo by M. Kossowski

criteria, especially functional and social ones (Wójcik 2009; Woods 2011).

The increase in social diversity of periurban areas, especially in the vicinity of large cities, has had a tremendous impact on differences in the perception of the social and natural environment. Residents were asked to give their two most important associations with the term 'countryside'. The answers were very varied, which proves the ambiguous social representation of rural areas (Fig. 15). An association with agriculture was the most frequent response (almost 33\%). 'Agriculture' was, however, given as a distinctive feature twice as often by long-term than by new residents. This is related to the origins of local communities, where this type of economic activity was until recently the main or an important source of income. Newcomers build their idea of the countryside mainly based on features associated with the landscape and environmental (ecological) aspects that serve as important motivations for choosing a location. Natural values and associated features of the surroundings (the environment), such as 'peace' and 'silence', as well as the landscape ('nice view') are fostering the stereotype of metropolitan villages. This perception of the countryside is typical in societies where there is a decline in the importance of the productive functions (agriculture) and all the burdens associated with the formation of new residential environments.

The generally low importance of the social value of the countryside, especially relating to the perception of the countryside as a community based on social closeness, is both important and telling. This feature was more often quoted by the long-term representatives of families, but even in their case the level of responses can be deemed very low.

Based on this, respondents were asked to indicate the features that distinguish contemporary countryside from other places in which to live and work, especially urban ones (Fig. 16). In this case, in contrast to the responses to the associations with the word 'countryside', 'lifestyle' characteristics were the most popular. Even though the concept of 'lifestyle' has broad social connotations, it most often referred to the differences in practice (behaviour, activities) of countryside 
residents based on the specific environmental and usability circumstances of the countryside. Respondents indicated various forms of contact with nature, feelings associated with experiencing 'open' space (landscape) that fostered better life harmony, the creation of a family atmosphere, better opportunities for spending time together, etc. The sense of a different lifestyle based on the rural environment was more often perceived by immigrants to the countryside. This is probably related to their greater awareness of the (chosen) villages' values that influenced their decision to change their place of residence, i.e. a move from the city to the countryside. In this case, in the eyes of new residents the 'rurality' is somehow 'made' in the process of confronting their expectations with the properties (realities) of the countryside. In the case of the so-called 'long-term' residents, the sense 'rurality' as a lifestyle comes naturally as it emerges from the continuity of living in the rural environment.

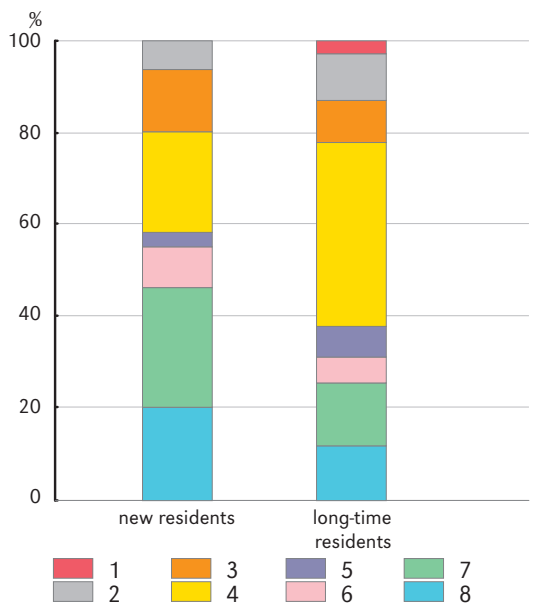

Figure 15. The structure of the respondents' responses to the question "What associations do you have with the word countryside?" (\%); 1. no answer, 2. others, 3. landscape, 4. agriculture, 5. social aspects, 6. idyll, 7. ecological values, 8 . peace and quiet

Other features listed by the respondents as distinguishing the countryside from other environments (especially cities) mostly related to the functional aspects. More often than newcomers, long-time residents indicated the different nature of the countryside based on other human activities (professional activities), especially agriculture, as well as the use of space, which related to a large extent to forms of agricultural development as well as to the landscape and settlement aspects.

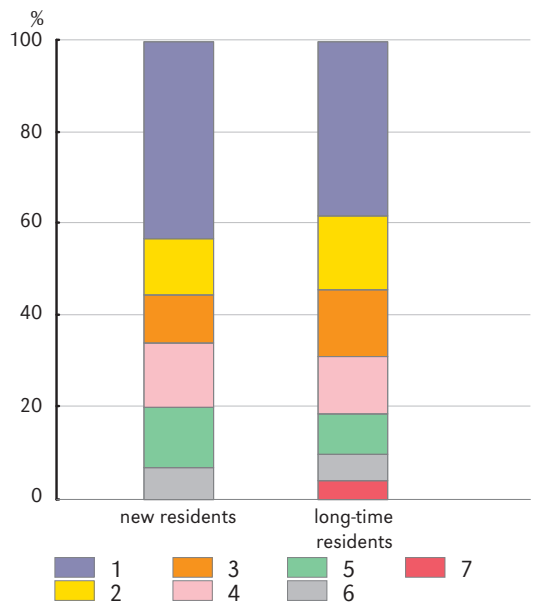

Figure 16. The structure of the respondents' responses to the question "Do you think that the countryside is different in any way from other places to live and work (e.g. the city)?" (\%); 1. different lifestyle, 2. different functions (agriculture, landscape protection, etc.), 3. landscape and physiognomic features, 4. worse infrastructure, 5. natural features, 6. others, 7. no answer

The difference in the perception of space is important for the overall context of the social image of the rural environment. This is primarily related to the recognition of the role of agriculture as a functional and social unifying force of the traditional countryside (the connection between the settlements and the fields). Newcomers tend to stress the distinctive features of the countryside from its inside, i.e. the settlement, which emphasises the sense of 'rurality' based on the fulfilment of the residential function. Long-time residents perceive the countryside in a more complex way, which is the result of the sense of 'long existence', but also of their relationship with the land. In this case, the perception 
of the countryside often has a second perspective, which includes the view of the home (homestead) from the field.

One characteristic feature of interviews with the residents of the countryside, both new and long-time, is the perception of the countryside in the context of natural circumstances, with the emphasis on both the context of nature itself (the natural environment) and the social and cultural dimension of the environment as a symbolic system. The disagrarianisation of peri-urban villages, especially the decreasing importance of agricultural production, leads to the growing social importance of natural characteristics and the consumption of the advantages related to them. The respondents were asked to expand on the descriptions of their behaviour related to their connection to nature. This task involved describing the form of their contact (relation) with nature (Fig. 17). Newcomers stressed that nature for them is primarily a structure giving them an opportunity for active leisure. That is why they pointed to regular walks in the neighbourhood and sports far more often than long-time residents. Indigenous residents mostly pointed to the importance of work, mostly agriculture, which involves observing nature, knowing how it influences work in the field, orchards and gardens. These respondents often emphasised that working in their homestead is an important element of leisure, especially for those who combine agriculture with another profession.

The structure of the area under their control is important to the variation in the behaviour of residents in this regard. Even though their building plots are often larger than long-time residents', newcomers do not have fields behind their homesteads. Movement outside of their property is forced to some extent by the limited area of their plots, while long-time residents have a great alternative to walks or bike rides in physical activity on their own fields and in their orchards and gardens. The spatial practices of newcomers are limited to the pre-determined routes of public roads, with occasional walks in the forests.

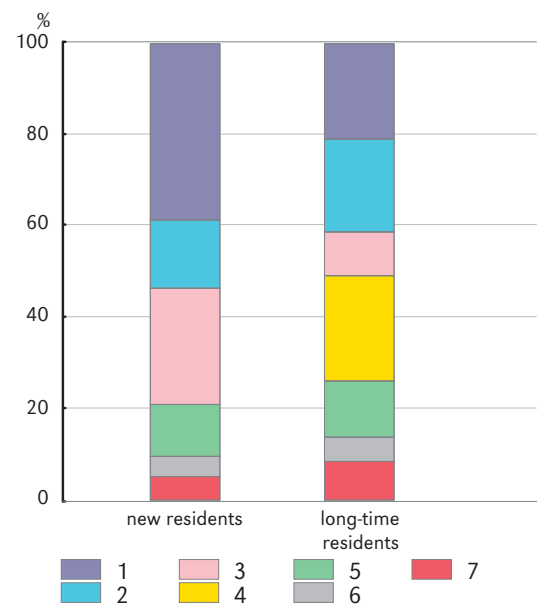

Figure 17. The structure of the respondents' answers to the question "How do you use (contact) nature?" (\%); 1. walks in the forest, 2. work and leisure in the garden, 3. active leisure (sport), 4. fieldwork (agriculture), 5. walks in the forest, 6. others, 7. no answer

Respondents were also asked to indicate on a scale of 1 (very low) to 5 (very high) the degree of their identification with certain areas, i.e. Poland, the region of Łódź, Łódź city, the rural municipality and their own village. The respondents identify most strongly with Poland and their place of residence (Fig. 18), this corresponds to the two most important categories of social identification of Poles, i.e. their identification with their ideological homeland (the country) and the 'little homeland' of the immediate vicinity (habitat).

In the case of new residents, the level of identification with all the areas listed above is the most even. This is due to their greater daily mobility and the formation of various types of territorial identity in certain stages of their lives (living in the metropolitan area, then on its peripheries). The territorial identity of new residents is shaped to a greater extent by their current place of residence (family home) than by their workplace or former places of residence, even if they spent more time there than in their current metropolitan village. Both groups show weak ties to the region, which is caused by the history of the emergence of the region based on functional 
factors (intense industrialisation and urbanisation in the 19th and 20th centuries).

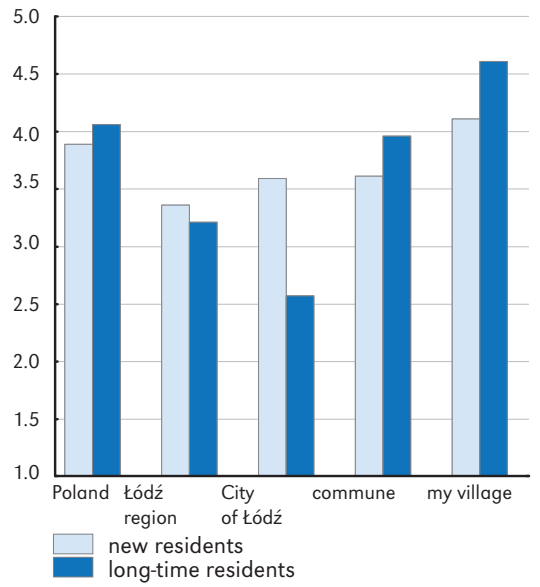

Figure 18. Level of identification of new and long-time residents with selected areas

In contrast to the new residents, people living in the villages for a long time and representing to a large extent the continuity of agrarian tradition identify more strongly with their place of residence, but also with the municipality. They operate to a greater extent in the local systems, fulfilling certain social needs in the centres of social and economic relations (e.g. in small towns, centres of municipalities) on the outskirts of the metropolitan built-up area.

The respondents were also asked to assess the positive and negative consequences of the influx of new residents to their village. In this case, the answers of respondents from both groups did not significantly differ (Figs. 19, 20). The indicated positive aspects of this process most often included the increasing population and expansion of the village. In the face of the depopulation of significant parts of the rural areas in the country and the region, the demographic and infrastructural improvement in peri-urban areas is a factor that has stimulated local enterprise and social initiatives. Residents emphasise the improving aesthetics of the countryside, which results mainly from new architectural forms, with the accompanying gardens. Respondents perceived the increasing diversity in the forms of development in a positive light, rarely noticing the growing chaos in development, their surroundings, etc.

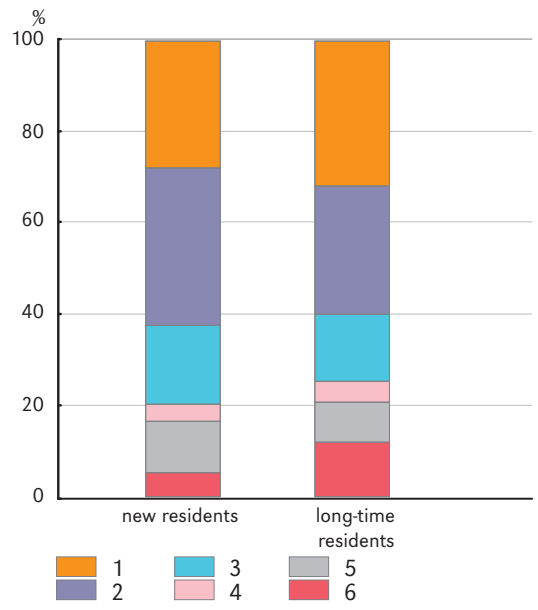

Figure 19. Structure of responses regarding the positive consequences of the influx of new residents; 1. increased population, 2. spatial development, 3. aesthetic values, 4. no positives, 5. others, 6. no answer

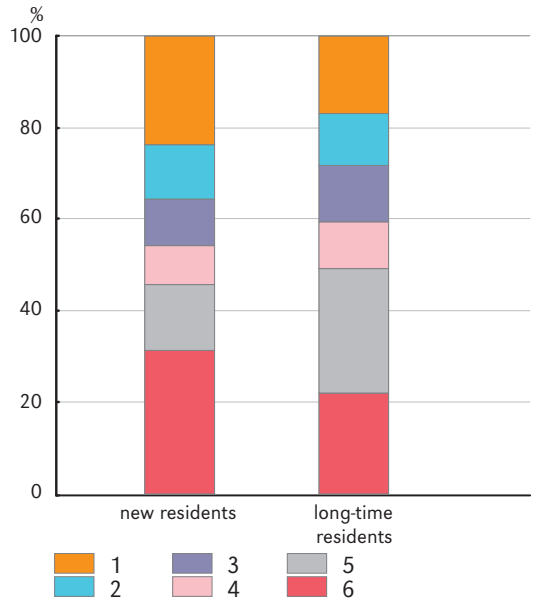

Figure 20. Structure of responses regarding the negative consequences of the influx of new residents; 1. fencing-off, 2. social disproportions, 3. expansion of new buildings, 4 . increased traffic, 5. others, 6. no answer

Negative consequences given by the respondents most often included social 
problems, i.e. the fencing-off of people (spatial and social separation), as well as the growing diversity of social groups seen as increasing inequalities.

Many respondents found the expansion of buildings and the development of open spaces to be a negative outcome. Residents also negatively perceived the increased traffic, which results from the growing population with different life styles, mainly working in the city (growing number of cars, traffic law violations). Long-term residents listed a lot of negative consequences that could not be categorised in larger groups. These included border disputes, disputes over the profits from land sales, the inappropriate behaviour of newcomers towards the local residents (such as showing off their higher social and material status). These responses demonstrate the growing diversity of contemporary countryside, both in animosities between the 'new' and the 'old' residents, but also among the indigenous population. Material differences, such as those resulting from the large amount earned from the sale of building plots, are effective in dividing communities into those able to profit from the situation and those that did not have such an opportunity.

The less fortunate are convinced that most benefits come to those powerful enough to influence the spatial planning of the rural municipalities which, in their opinion, is a function of their ties to local authorities.

\section{Discussion}

The problem of the formation of the specificity of the social environment in the urban fringe should also be looked at more broadly, from a more relative point of view. This is due to the contemporary nature of the settlement network, interpreted in terms of a continuum. In the case of rural settlements or rural settlement systems, discussing them in terms of their daily activities requires considering their socio-cultural characteristics. In such a situation, special attention is paid to the socio-spatial behaviour patterns stemming from the historical continuity of certain individual characteristics of functioning within a local structure. The functional concepts describing the diversity of settlements within the social and professional structures evolve towards the perception of social needs and the resulting socio-spatial behaviour.

Rural settlements are 'arenas' of social processes (Woods 2011; Wójcik 2012) where individuals (people) meet not only social, but also natural structures. This is the fundamental difference in the development and interpretation of the specificity of the features of rural life in the circumstances of the diminishing significance of economic (mainly agricultural) functions and the development of residential and other non-economic functions (the rise of the post-productivist countryside). The study illustrates selected social consequences of spatial policy regarding housing in rural municipalities in the urban fringe of a big city. The results show that this process generally leads to socio-spatial diversification. Unlike macro-scale studies, both Polish (Marcińczak 2013) and foreign (such as Leetmaa \& Tammaru 2007) micro-scale studies have shown that differences are even greater and concern neighbouring areas (cultural differences and contrasts). The results confirm the findings of other Polish work, especially in sociology and anthropology (Halamska 2011; Mantey 2011; Kajdanek 2012), concerning growing social disintegration, the mutual distrust of human groups, and a clash between expectations (search for ideal living conditions) and the reality of the urbanised countryside, especially a lack of satisfaction with one's neighbourhood. As a result of the influx of new residents to peri-urban villages, longtime communities of agrarian origin evolve towards social-spatial disintegration. Villagers become users of the same area (village) rather than social communities. The different ways of life are manifested in different behaviour patterns and levels of territorial identity. New residents of a village perceive space primarily in terms of functional utility (convenience of residence), while long-time residents attach traditional values to rural areas. 
Even though it is caused by vastly different systems of perception and meaning, the integration of people with their local environment is largely built upon the sense of rurality, but what is understood by this notion by different social groups derives from different mental backgrounds and interpretations. Examples of studies on the evaluation of the local living environment show that the social coherence of the countryside is gradually weakening, resulting mostly from more and more varied lifestyles, social needs and expectations towards their place of residence. Various forms of social life are created on the basis of the same system of material resources of the countryside (land, territory). The relativisation of the understanding of 'countryside' is related to the ways it is constructed, i.e. it stems from social representations - forms

\section{References}

BAŃSKI J., 2008. Odrębność obszaru podmiejskiego w kontinuum miejsko-wiejskim. Czasopismo Geograficzne, vol. 80, np. 4, pp. 210-228.

BAŃSKI J., WESOŁOWSKA M., 2012. Transformation in housing construction in rural areas of Poland's Lublin region - influence on the spatial settlement structure and landscape aesthetics. Landscape and Urban Planning, vol. 94, no. 2, pp. 116-126.

Bıczkowskı M., KozŁowskı L. (eds.), 2015. Wiejskie obszary funkcjonalne. Studia Obszarów Wiejskich, 37, Warszawa: Komisja Obszaru Wiejskich PTG, Instytut Geografii i Przestrzenengo Zagospodarowania PAN.

Blacksell M., Born K.M., 2002. Private property restitution: The geographical consequence of official government policies in Central and Eastern Europe. The Geographical Journal, vol. 168, no. 2, pp. 178-190.

Borén T., Gentile M., 2007. Metropolitan processes in post-communist states. An introduction [in:] T. Borén, M. Gentile (eds.), Metropolitan processes in post-communist States, Geografiska Annaler, Series B, Human Geography, vol. 89 , no. 2, pp. 95-110. of judgements and ideas. The countryside under transformation, in the transient period, is somewhere in-between. This 'in-between' means not only a point on a scale of formal urbanisation, but, above all, refers to its suspension among the representations (ideas) of rurality.

\section{Acknowledgements}

This paper is the result of the financial support of the National Science Centre, Poland (grant number NN 306140238).

\section{Editors' note:}

Unless otherwise stated, the sources of tables and figures are the authors', on the basis of their own research.

Champion T., 2001. Urbanization, suburbanization, counterurbanization and reurbanization [in:] R. Paddison (ed.), Handbook of Urban Studies, London: Sage.

CLARK D., 1982. Urban geography. London, Oxford, Worcester: Billing and Sons Limited.

Connell J., 1974. The metropolitan village [in:] J.H. Johnson, Suburban growth, London: Wiley.

GEYER H.S. (ed.), 2002. International handbook of urban systems: Studies of urbanization and migration in advanced and developing countries. Cheltenham: E. Elgar.

Gierańczyk W., Kluba M. (eds.), 2008. Problemy i metody oceny kontinuum miejsko-wiejskiego w Polsce. Studia Obszarów Wiejskich, 13, Warszawa: Komisja Obszaru Wiejskich PTG, Instytut Geografii i Przestrzenengo Zagospodarowania PAN.

GORLACH K., 2004. Socjologia obszarów wiejskich. Problemy i perspektywy. Warszawa: Wydawnictwo Naukowe Scholar.

GUS, 1984. Aglomeracje Miejskie w 1983. Warszawa: Główny Urząd Statystyczny.

GUtry-KoryCKA M. (ed.), 2005. Urban sprawl: Warsaw Agglomeration case study. Warsaw: Warsaw University. 
HalAMSKA M., 2011. Wieś jako przedmiot badań naukowych [in:] M. Halamska (ed.), Wieś jako przedmiot badań naukowych na początku XXI w., Warszawa: Wydawnictwo Naukowe Scholar, pp. 225-240.

HALFACREE K., 2009. Rurality and post-rurality [in:] R. Kitchin, N. Thrift (eds.), International Encyclopedia of Human Geography, vol. 9, Elsevier, pp. 449-456.

ILBERY B., 1998. The Geography of Rural Change. Harlow: Pearson.

JAKÓBCZYK-GRYSZKIEWICZ J., 1998. Przeobrażenia stref podmiejskich dużych miast. Studium porównawcze strefy podmiejskiej Warszawy, Łodzi i Krakowa. Łódź: Wydawnictwo Uniwersytetu Łódzkiego.

JAKÓBCZYK-GRYSZKIEWICZ J., 2009. Tendencje przestrzenne w kształtowaniu cen ziemi w Polsce po 1990 roku, Łódź: Wydawnictwo Uniwersytetu Łódzkiego.

Jakóbczyk-GryszkieWicz J., Marcińczak S., SiejKOWSKA A., 2010. Dynamika i skutki procesów urbanizacji w regionach miejskich po 1990 roku na przykładzie regionu miejskiego Łodzi. Łódź: Wydawnictwo Uniwersytetu Łódzkiego.

KAJDANEK K., 2011. Suburbanizacja na przykładzie osiedli podmiejskich Wrocławia. Kraków: Nomos.

KAJDANEK K., 2012. Suburbanizacja po polsku. Kraków: Nomos.

Komornicki T., 2013. Propozycje wskaźników powiqzań [in:] Wskaźniki zagospodarowania i ładu przestrzennego w gminach, Biuletyn Komitetu Przestrzennego Zagospodarowania Kraju PAN, 252, Warszawa: Komitet Przestrzennego Zagospodarowania Kraju PAN, pp. 164-175.

Kovács Z., 2009. Social and economic transformation of historical neighborhoods in Budapest. Tijdschrift voor Economische en Sociale Geografie, vol. 100, no. 4, pp. 399-416.

LeetmaA K., Tammaru T., 2007. Suburbanization in countries in transition: Destinations of suburbanizers in the Tallin Metropolitan Area. Geografiska Annaler: Series B. Human Geography, vol. 89, no., 2, pp. 127-146.

LIszewski S., Young C. (eds.), 1997. A comparative study of Łódź and Manchester: Geographies of European cities in transition. Łódź: University of Łódź.
Macnaghten P., URRY J., 1998. Contested natures. London-New Delhi: Thousand Oaks.

Mantey D., 2011. Żywiołowość lokalizacji osiedli mieszkaniowych na trenach wiejskich obszaru metropolitalnego Warszawy. Warszawa: Uniwersytet Warszawski.

MarcińcZAK S., 2013. Segregacja społeczna w mieście postsocjalistycznym. Bukareszt, Warszawa, Tallin na poczqtku XXI w. Łódź: Wydawnictwo Uniwersytetu Łódzkiego.

Milewska-OsieCKa K., 2010. Nowe budownictwo mieszkaniowe aglomeracji tódzkiej. Zróżnicowanie i struktura przestrzenna. Łódź: Wydawnictwo Uniwersytetu Łódzkiego.

OUŘEDníčEK M., 2007. Differential suburban development in the Prague urban region. Geografiska Annaler: Series B. Human Geography, vol. 89, no. 2, pp. 111-126.

Pacione M., 1984. Rural Geography. London: Harper and Row.

PAHL R., 1965. Urbs in rure: the Metropolitan Fringe in Hertfordshire. Geographical Paper, 2, London: London School of Economics and Political Science.

PHILLIPS M., 2002. The production, symbolization and socialization of gentrification: impressions from two Berkshire villages. Transactions of the Institute of British Geographers, vol. 27, no. 3, pp. 283-308.

PHILIPS M., 2005. Differential productions of rural gentrifications: Illustrations from North and South Norfolk. Geoforum, vol. 36, no. 4, pp. 477-494.

PIÓRO Z., 1982. Główne nurty ekologii społecznej [in:] Z. Pióro (ed.), Przestrzeń i społeczeństwo. Z badań ekologii czynnikowej, Warszawa: Wydawnictwo Ksiq̨żka i Wiedza, pp. 7-51.

SIBLEY D., 1999. Creating geographies of difference [in:] D. Massey, J. Allen, P. Sarre (eds.), Human Geography Today, Cambridge: Polity Press.

SMITH D.M., 1989. Urban inequality under socialism: Case studies from Eastern Europe and the Soviet Union. Cambridge: Cambridge University Press.

Starosta P., 1995. Poza metropoliq. Wiejskie i małomiasteczkowe zbiorowości lokalne a wzory porzadku makrospołecznego. Łódź: Wydawnictwo Uniwersytetu Łódzkiego. 
Straszewicz L., 1985. Strefa podmiejska. Pojęcia i definicje [in:] L. Straszewicz (ed.), Pojęcia i metody badań strefy podmiejskiej, Acta Universitatis Lodziensis, Folia Geographica, vol. 5, pp. 7-16.

Suliborski A., Wójcik M., KulaWiak A., 2009. Spatial and funcional changes in Łódź after the socio-ecomonic transformation. Quaestiones Geographicae. Series B: Human Geography and Spatial Management, 28B/2, pp. 71-89.

SÝKORA L., 1999. Changes in the internal structure of post-communist Prague. GeoJournal, vol. 49, no. 1, pp. 79-89.

ŚLESZYŃSKI P., 2014. Procesy suburbanizacji w Polsce a polityka przestrzenna i regionalna [in:] A. Wolaniuk (ed.), Centra i peryferie w okresie transformacji ustrojowej: XXVII Konwersatorium Wiedzy o Mieście, Łódź: Wydawnictwo Uniwersytetu Łódzkiego, pp. 11-25.

ŚwIĄTEK D., 2010. Infrastruktura techniczna a rozwój pozarolniczej działalności gospodarczej w regionie Płocka. Studia Obszarów Wiejskich, 25, Warszawa: Komisja Obszaru Wiejskich PTG, Instytut Geografii i Przestrzennego Zagospodarowania PAN.

TAMmARU T., 1999. Differential urbanisation and primate city growth in soviet and post-soviet Estonia. Tijdschrift voor economische en sociale geografie, vol. 91, no. 1, pp. 20-30.

TKocz J., 1998. Organizacja przestrzenna wsi w Polsce. Katowice: Wydawnictwo Uniwersytetu Śląskiego.

Urzad Statystyczny w ŁodzI, 2008. Próba delimitacji obszaru metropolitalnego Łodzi na podstawie ruchu wędrówkowego ludności w latach 1989-2007. Łódź [collective work].
WeSSEL T., 2000. Social polarization and socioeconomic segregation in a welfare state: The case of Oslo. Urban Studies, vol. 37, no. 10, pp. 1947-1967.

WECŁAWOWICZ G., 1979. The structure of socioeconomic space in Warsaw in 1931 and 1970: A study in factorial ecology [in:] R.A. French, F. E. I. Hamilton (eds.), The socialist city: Spatial structure and urban policy, Chichester: John Wiley and Sons, pp. 387-424.

WECŁAWOWICZ G., 2002. From egalitarian cities in theory to non-egalitarian cities in practice: The changing social and spatial patters in Polish cities [in:] P. Marcuse, R. Van Kempen (eds.), Of States and Cities: The partitioning of urban space, Oxford: Oxford University Press, pp. 183-199.

Woods M., 2011. Rural. New York: Routledge.

Wóscik M., 2008. Przemiany społeczno-gospodarcze wsi w okresie transformacji ustrojowej. Łódź: Wydawnictwo Uniwersytetu Łódzkiego.

Wóscik M., 2009. Społeczna geografia wsi. Czasopismo Geograficzne, vol. 80, no. 1-2, pp. 42-62.

Wóscik M., 2013a. Przemiany społeczno-przestrzenne osiedli wiejskich. Studium przypadku Łódzkiego Obszaru Metropolitalnego, Łódź: Wydawnictwo Uniwersytetu Łódzkiego.

Wóscik M., 2013b. Gentryfikacja wsi - "jak daleko od miasta" [in:] J. Jakóbczyk-Gryszkiewicz (ed.), Procesy gentryfikacji, cz. II: XXVI Konwersatorium Wiedzy o Mieście, Łódź: Wydawnictwo Uniwersytetu Łódzkiego, pp. 165-174.
(C) Marcin Wójcik

(C) Geographia Polonica

(C) Institute of Geography and Spatial Organization

Polish Academy of Sciences - Warsaw • 2016
Article first received • January 2015 Article accepted • February 2016 